to scaber: no distinction, such as is now usual, is made between triangular, triquetrous, and trigonous: cuspidate is defined as almost, if not quite, synonymous with acuminate, but most modern descriptive botanists distinguish carefully between them, considering a cuspidate organ to be one which is abruptly acuminate, $i$. e. bluntly rounded at the end, but with a point large at its base but gradually narrowed upwards placed upon it.

The British Botanist's Field-book : a Synopsis of the British Flowering Plants. By A. P. Childs, F.R.C.S. Post 8 vo. London, 1857.

We are sorry that it is not in our power to give a favourable account of this book, for the author's object is manifestly good. He has undertaken that which we believe to be nearly impossible, namely to produce a book containing "the essential marks, and those alone, by which each order, genus, and species may be distinguished." Modestly, he does not pretend to have fully succeeded, but the very fact of publication proves his belief that to a great extent he has done so. It might be supposed that the task is not so very difficult, for we find authors like Arnott and Babington giving, in their respective Floras, something which at the first view might be supposed to supply the materials for such a book as this before us. Upon a more careful examination, it will be found that this is far from being the case; for Dr. Arnott's tabular views of the orders and genera are accompanied by fuller characters, by which the group may be determined with greater certainty; and the italicized parts of the specific characters in Mr. Babington's Manual are so prepared as to help in the determination of the species by showing to what point it is desirable that attention should primarily be given, but do not profess to distinguish the species from all its allies inhabiting this country, far less from those found upon the European continent, for an examination of the remainder of the character is requisite to do that. Even supposing that the present author had succeeded in his object, we should consider the book as likely to be more injurious than otherwise to the science of botany. Great advances have been made of late years in our knowledge of the plants of Britain, and many additions to the list discovered, which even Mr. Childs allows to be deserving of notice. But would this advance have taken place if our descriptive books had been written by men who confined their study to Britain alone, or, if their reading was more extensive, showed no trace of it in their books? Should not we have remained in the condition in which botany stagnated for so many years, when collectors were satisfied if they could force their specimens to conform to some description given in the works of Smith; and when it was supposed, as we well remember, that no new plants remained to be added to our flora? In the book before us, and in others in this respect resembling it, which we have thought it unnecessary to notice, there is nothing to cause the reader to suppose that further knowledge is desirable. He has discovered the name of his plant, or thinks that Ann. \& Mag. N. Hist. Ser. 2. Vol. xix. 
he has done so; has no idea that other species are allied to it, the characters of which it is desirable for him to examine; and he-a mere collector-is led to suppose himself to be a botanist. It may, perhaps, be said that in the book before us the author disclaims all intention of advancing science; but, as he wrote it expressly as a field-companion, and states, although incorrectly, that it is the only modern field-book which is portable, he ought to have taken care that it supplied all that is likely to be required in the field. The book should have been called "A Synopsis of the best-known British Plants," for nearly all those which present the slightest difficulty or doubt are omitted, and stigmatized as the result of " minute and useless subdivision." Our experience of students in the field has taught us that it is not the distinctive points of the common and well-known species which they require to have always at hand, for with such plants they very soon become familiar, but that the characters supposed to separate those which are dubious or critical are often asked for. Mr. Childs treats this want as non-existent, and no reader of his book alone would discover that there are such plants, or that botanists have ever differed about them. The author probably supposes that his book is to lead its readers to the use of others of a more elaborate character ; but he must know that many of them will rest satisfied without that further study, to which he certainly does not encourage them to proceed.

The proper sequence of the Orders is not determined by botanists, but most authors have thought it well to follow a uniform system founded upon that of DeCandolle. Mr. Childs has deviated from this, and arranged them in a totally different manner. His plan may be good (although we have great doubts upon the subject), but we know experimentally the extreme inconvenience caused, even to those who have made some advance in botany, by deserting the usual order. To the beginner this is of great consequence, for his facility in using other books will be much diminished by having learned to look for plants in a different position in the series from that which they occupy in all the best Floras of this and other countries.

PROCEEDINGS OF LEARNED SOCIETIES.

\section{ZOOLOGICAL SOCIETY.}

\section{November 25, 1856.-J. S. Gaskoin, Esq., F.L.S., in the Chair.}

Mr. Tegetmeier brought before the notice of the Members living specimens and preparations illustrating the very remarkable peculiarities existing in the skulls of the feather-crested variety of the domestic Fowl, now known as Polish. In these birds, the anterior portion of the frontal bone is expanded into a large spherical tuberosity or cyst, which is partly osseous and partly membranous; the anterior portions of the brain are entirely contained in this tuberosity, 


\section{$2 \mathrm{BHL}$ Biodiversity Heritage Library}

1857. "The British botanist's field-book: a synopsis of the British flowering plants. By A. P. Childs, F.R.C.S. Post 8vo. London, 1857." The Annals and magazine of natural history; zoology, botany, and geology 19, 481-482. https://doi.org/10.1080/00222935708693973.

View This Item Online: https://www.biodiversitylibrary.org/item/19414

DOI: https://doi.org/10.1080/00222935708693973

Permalink: https://www.biodiversitylibrary.org/partpdf/26033

\section{Holding Institution}

Natural History Museum Library, London

\section{Sponsored by}

Natural History Museum Library, London

\section{Copyright \& Reuse}

Copyright Status: Public domain. The BHL considers that this work is no longer under copyright protection.

This document was created from content at the Biodiversity Heritage Library, the world's largest open access digital library for biodiversity literature and archives. Visit BHL at https://www.biodiversitylibrary.org. 